\title{
Ownership of Copyright in Works Created During Employment Relationships
}

\author{
Naim Spahiu \\ Phd Can.Lecturer at University of Prizren "Ukshin Hoti" Law Faculty,
}

Halim Bajraktari

Prof. Ass. Dr. University of Prizren" Ukshin Hoti" Law Faculty. Vice Dean.

Florin Lata

Mr.sc, Member of Kosovo Bar Association, Cofounder of law firm "Judex"

\begin{abstract}
The copyright in its infancy was provide protection only for the category of works of fine art but challenges followed by creations immediately should be undertaken measures regarding copyright during employment relationship. When authors of creations have seen the benefit of copyrights, they have risen their voice and acted to protect their creation. Therefore, it is very important that employers and employees with employment contract or agreement later make accurate determinations and clearly define their agreement. Law on Copyright in Kosovo almost every provision cited in this article has left open the possibility of defining many issues between parties, such as the expiration of period of rights to the employer, extra compensation etc. In the absence of clear contractual provisions shall apply copyright, and companies, that have invested heavily in a certain work, will lose right after the expiration of 10 years and all contracts that are associated with third parties, other-companies for allowing the use of a work after this deadline will be invalid because a party cannot achieve the right of copyright. This situation could cause many problems in the future for Kosovo companies which do not have much knowledge about the legislation in the field of copyright and do not take precautions to regulate the issue of transfer of rights to their employees. This Article discusses the idea ownership issue in the context of employment and independent contractor relationships. The paper recommends that since copyright is not familiar with the business regarding changing performance, therefore Kosovo laws should adequately support these circumstances of ownership in order for employees to give their best on his career. How employees could be owners of copyright. Which particular articles of Kosovo law on copyright should change?
\end{abstract}

Keywords: Copyright, employee, employ motivation, law, Kosovo.

\section{Introduction}

In its beginnings, the copyright provided protection to the category of pieces of fine works only. However, as the time passed by, its scope extended to other fields as well (such as photography, computer programs), particularly to the applied arts, (architecture, marketing, design, clothes designs, etc.) where the majority of these works were created during employment ${ }^{1}$. So, it is appropriate to make a question - to whom does the copyright belong as far the works created by an employee in his/her employments are concerned? In order to give an answer to this question, in the beginning, there should be made a distinction between the notion of the author and the copyright holder!.

The Law on Copyright and Related Rights No. 04/L-065, article 13, expressly provides as follows "An author is the natural person who created the work". Thus, in principle, the law excluded the legal person, namely the companies, from the option to be considered an author to the respective work. Certainly, this principle is substantiated on foundation of the copyright law itself, which protects the original intellectual creations in the field of literature, science and art (see article 8 of the Law

\footnotetext{
${ }^{1}$ A. Bertrand, "Copyright” Dalloz, Paris, 2010, p. 187.
} 
on Copyright). Thus, an author of a work which is protected by a copyright may be a natural person only because the works represent a product of human creativity who through work expresses his own artistic personality.

However, there are certain copyrights which may be transferred from the author to the natural person by means of an agreement or in other cases as set out with the law. When the property rights are transferred through contract or copyright law, a natural or legal person who has received such rights, is considered holder of the copyright. Thus, the author of the work can be a natural person only, and the holder of such right can be either a natural or a legal person. One of the rights set out by the law when the author of a work is not also the holder of right is related to the cases of author's-employee's work who created its work whilst carrying out his/her daily duties and activities.

The Law on Copyright and Related Rights No. 04/L-065, article 126, para. 1, sets out as follows: "When the author's work is created by the employee during his/her employment, whilst carrying out his/her duties or according to the instructions given by the employer, it is considered that the property rights and other author's rights were assigned exclusively and without limitations to the employer, for a period of ten (10) years, since the completion of the work, unless otherwise Provided by the employment contract or by another signed act with the employer". This act sets out the transfer of rights from the author who is a natural person/employee to the employer. The law provides a 10 -year validity of the rights assignment - thus the author's rights are assigned to the employer on temporarily basis only, unless otherwise provided under the contract. The law does not exclude the option that the parties may agree to another term which is set out in the contract concluded between each other. The Law on Copyright and other related rights No. 35/2016 of the Republic of Albania provides a 3-year term only relating to assignment of works from the employee author to the employer ${ }^{1}$.

For an employer to be considered the holder of works rights which were created by his/her employees, s/he should meet two requirements cumulatively, the first one, the work should have been created during his/her employment and the second one, the work should have been created by conducting the job tasks by the author. The Kosovar Labour, Law No. 03/L212 , article 3 , section 1.10, defines the labour relation as "an agreement or contractual arrangement between an employer and an employee for the performance of specified functions or tasks by the employee under the supervision of the employer in return for an agreed remuneration, normally in the form of money". ${ }^{2}$ This means that in order to establish a normal lab our relation, the parties should conclude an employment agreement which the law defines it as "an individual act which is concluded by and between the employer and employee, which set out the rights, duties and responsibilities arising out or in connection with the employment agreement pursuant to this law, collective agreement and the employer's internal act". Given the fact that the informality rate in the Kosovo labour market is high (there are no accurate statistics) where there many employees without employment agreements, we consider that there will arise quite problematic situations in a near future where the current employees, after they realize that they are entitled to additional rights for their works, shall file lawsuits with the courts to claim their rights. The employers who neither declared their employees nor offered them employment agreements with the sole purpose of avoiding taxes, in our opinion, shall not benefit from the application of article 126, consequently s/he shall not be considered a holder of copyright.

Therefore, even from this point of view, the employers who do not offer employment agreements to their employees risk at a later stage to lose any right over the created works by their employees during their employment and to be subject to lawsuit for copyright violations.

In addition to the labour relation as the first requirement, the work should be created by an author/employee whilst carrying out his/her duties. The same concept can be found under the Law on Patents No. 04/L-029, respectively article 20, para. 3 which sets out as follows "... when an invention is made in the Republic of Kosovo in execution of a commission or an employment contract, the right to the patent shall belong to the person having commissioned the work or to the employer, unless it is foreseen otherwise by the contract"3.

As it is widely known, the job description is determined by the employment agreement and the employer's internal acts. If an employee has created a work which was not defined under his/her job description duties, the employer shall be

\footnotetext{
1 The Republic of Albania, Law on Copyright and other related rights No. 35/2016.

2 For more see in: Law No. 03/L-212, article 3.

${ }^{3}$ For more see in: Law on Patents No. 04/L-029.
} 
considered the holder of such rights although such work might have been created during his/her employment. In such cases, the employer should conclude an employment agreement with the employee in order to assign the copyrights.

But, is the employee entitled that in event of termination of employment agreement to use his/her work without any limitation before the expiration of a 10-year period as set out with the law? Although the law does not provide such a thing, it is considered that an employee, even in event of termination of employment agreement, before a 10-year period, may use his/her own work because by doing so s/he would make disloyal competition or would breach the confidentiality clause, certainly, in case the employee created his/her work by using his knowledge gained during his/her employment.

Further, the article 126, para. 2 provides as follows "... the rights shall be returned the employed author prior to expiration of such term, in case of employer's death, respectively in case of employer's liquidation as a legal person". Thus, in case the employer dies or the legal person is subject to liquidation, the author's right shall be returned to the employed author even if the 10-year term has not passed yet.

This legal formulation means that there is no need for any formality by the employee in event of the above-noted cases, it is sufficient to notify the employee about the employer's death or the company's liquidation.

Whereas, the para. 4 of the same article provides as follows "Unless otherwise contracted between the author and employer, the employee, as the author of the work enjoys the right to claim additional compensation from the employer, if his/her salary evident disproportion with the incomings and savings realized due to the use of the work". As per this provision, the author may request additional compensation, except his/her salary, by the employer, in events when the company achieved higher revenues from his/her work, provided that it is not provided otherwise under the agreement. According to our evaluation, such a provision is difficult to be enforced.

This takes place because it is very subjective the evaluation of disproportion between the salary and achieved revenue as a result of the work. The Law of Republic of Albania on the Copyright ${ }^{1}$ has settled better this matter because it sets a limit to the additional compensation, except for the salary, onlyto cases when the employer assigns the copyright to a third party, and not for cases when the work is used for its own needs. The Albanian law also provides another quite interesting limitation relating to the use of the work of the employed author. The employer may use such a work only within his own activity scope as also defined under the employment agreement, while for other cases the employer has to seek prior written approval from the author who shall be entitled to additional remuneration. There are similarities even under the section "additional compensation" with the concept of the law on patents where the compensation amount is determined in proportion with the patent market value. A completely different practice can be found under the French law which under the article 111-1 para. 3 of the Code on Intellectual Property, expressly provides that the existence of a service agreement (including employment agreement) shall not serve as basis to assign copyright. Under the French System, the employed author, at any time after the creation of a protected work by copyright, may assign the property rights to the company where s/he works through a written agreement. The employee, in addition to his/her salary, shall be entitled to additional compensation.

The applicable law in Kosovo, article 128, provides exceptions from the said rule with regard to collective works which were created by an order, computer programs and databasis. In such cases, the law provides the assignment of all rights from the employed author to the person who ordered the work or to the company exclusively and without limitations. In terms of the author's collective works, pursuant to article 106, para 4, the requester of collective work of author enjoys the right to publish and use the work under his own name, however in each copy of work the list of participating authors shall be placed.

It is worth mentionioning that regardless who is the holder of the property right and other copyright ${ }^{2}$, the author's moral rights (the right of authorship recongition, of first publication, of work integrity and repentance right) shall not be assigned to third parties- neither to the employer - but they shall remain the author's work. The assignment of author's moral rights is prohibited by law for the purpose of the author's own protection who might be under pressure to assign all rights. The

\footnotetext{
${ }^{1}$ Article 69 para 4 of the Law on Copyright and other related rights №. 35/2016 of the Republic of Albania provides that "In the cases when the employer, as per the employment agreement with the employed author, assigns the author's right or authorizes a third party to use the work for profit purposes, the author shall be entitled to remuneration in proportion with the gained profit by the authorization/assignment of rights to third parties.

${ }^{2}$ Chapter III of the Law on Copyright stipulates that other author's rights are the right to access and expose, right on resale, the right of public borrowing and the right to special compensation.
} 
author, even if he is not the holder of economic rights for his/her own works, he shall again remain its author and such a right shall be valid for unlimited time.

Therefore, it is very important the employer and employee provide specific arrangements and clear definitions under their employment agreement or under a later agreement. The Copyright Law, almost under each of its written cited provision, has left open the option to the parties to define many issues through an agreement such as the following: to determine the term of assignment of rights to the employer, additional compensation, etc. In absence of such clear contractual provisions, the legal provisions shall be applicable and the companies which have invested a lot on a certain work, shall lose the copyright after the 10-year period has expired. Consequently, all the contracts concluded with third parties/other companies to grant permission for the use of such work, shall be deemed invalid following the expiration of such period, because a party shall not assign a right to another party for a right which s/he does not hold. This situation could cause countless problems to Kosovan companies in future which do not have much knowledge about the copyright law and do not take any prior action to settle the issue with their employees regarding the assignment of rights.

\section{Literature:}

[1] Bertrand, "Copyright" Dalloz, Paris, 2010.

[2] The Law on Copyright and Related Rights No. 04/L-065 Republic of Kosovo.

[3] Dega Fatos, "Intelectual Property" Third edition 2012, Morava, Tiranw.

[4] Law on Copyright and other related rights No. 35/2016 of the Republic of Albania.

[5] "Intellectual Property, A Power Tool for Economic Growth by Kamil Idris, WIPO Pub. No. 888", January 2003"

[6] "Claas Junghans, Adam Levy, (Intellectual property management) ", Germany, 2006.

[7] BGV \& Partenaires, avocats et consultants 23 place Bellecour, 69002 Lyon, France.

[8] Essentials of intellectual property", Alexander I Poltorak, Paul J. Lerner, USA, 2002.

[9] Law on Patents No. 04/L-029 Republic of Kosovo.

[10] Labor, Law No. 03/L-212 Republic of Kosovo.

[11] "WIPO Intellectual Property Handbook": Policy, Law and Use WIPO 2004

[12] "WIPO intellectual property Handbook", Wipo Poblication no.489. 2001.

[13] "Dealing with vialators of intellectual property rights" WIPO Magazine/ Jan- Feb. 2004. 